\title{
MCH-R1 Antagonists as Potential Anti-obesity Drugs. Design Strategies and Structure-activity Relationship
}

\author{
Rivera, G.;* Moreno, A.; Bocanegra-García, V.
}

Rev. Virtual Quim., 2013, 5 (6), 1156-1178. Data de publicação na Web: 3 de setembro de 2013

\author{
http://www.uff.br/rvq
}

\section{Antagonistas MCH-R1 como Potenciais Fármacos Anti-obesidade. Estratégias de Design e Relação Estrutura-atividade}

Resumo: A obesidade é uma doença crônica que é caracterizada por um acúmulo de excesso de tecido adiposo. Atualmente, existem alguns medicamentos seguros e eficazes para o tratamento farmacológico da obesidade. Portanto, torna-se necessário o desenvolvimento de novas drogas. Na última década, o alvo mais promissor para a obesidade foi o hormônio concentrador de melanina. Com isso, diversas indústrias farmacêuticas desenvolveram peptídeos e pequenas moléculas como antagonistas $\mathrm{MCH}-\mathrm{R} 1$, mas estes compostos apresentaram problemas como afinidade para o canal hERG e perfil farmacocinético pobre. Neste artigo, fizemos uma breve revisão da concepção da estratégia mais relevante e relações da estrutura-atividade no desenvolvimento de carboxamida, ureias, quinolina e derivados quinazolina como antagonistas MCH-R1.

Palavras-chave: Antagonistas; hormônio concentrador de melanina; obesidade.

\begin{abstract}
Obesity is a chronic disease that is characterized by an accumulation of excess adipose tissue. Actually, there are few safe and effective drugs for pharmacological treatment of obesity. Therefore, it becomes necessary the development of new drugs. In the last decade, the most promising target for obesity was melanin-concentrating hormone. Thereat, diverse pharmaceutical companies developed peptides and small molecules as $\mathrm{MCH}-\mathrm{R} 1$ antagonists, but, these compounds had problems as affinity for hERG channel and poor pharmacokinetic profile. In this manuscript, we made a brief review of the most relevant strategy design and structure-activity relationships in the development of carboxamide, ureas, quinoline, and quinazoline derivatives as $\mathrm{MCH}-\mathrm{R} 1$ antagonists.
\end{abstract}

Keywords: Antagonists; melanin-concentrating hormone; obesity.

\footnotetext{
* Instituto Politécnico Nacional, Centro de Biotecnología Genómica, Boulevard del Maestro, s/n, Esq. Elías Piña, 88710, Reynosa, México. Phone: +52 899 9243627, Fax: +52 8999243628.

Mgildardors@hotmail.com DOI: $10.5935 / 1984-6835.20130084$
} 


\section{MCH-R1 Antagonists as Potential Anti-obesity Drugs. Design Strategies and Structure-activity Relationship Gildardo Rivera, ${ }^{a, *}$ Antonio Moreno, ${ }^{b}$ Virgilio Bocanegra-García ${ }^{a}$}

a Instituto Politécnico Nacional, Centro de Biotecnología Genómica, Boulevard del Maestro, s/n, Esq. Elías Piña, 88710, Reynosa, México. Phone: +52 899 9243627, Fax: +52 8999243628.

${ }^{\mathrm{b}}$ University of Córdoba, Department of Cell Biology, Physiology and Immunology, Reina Sofía University Hospital, Instituto Maimónides de Investigación Biomédica de Córdoba (IMIBIC); CIBER Fisiopatología de la Obesidad y Nutrición (CIBERobn); 14014, Córdoba, Spain.

* gildardors@hotmail.com

Recebido em 5 de abril de 2013. Aceito para publicação em 25 de agosto de 2013

\section{Introduction}

1.1. Pharmacological approach

1.2. Drug targets for obesity

2. Melanin-concentrating hormone (MCH)

\section{MCH-R1 Antagonists}

3.1. Peptide derivatives

3.2. Carboxamide derivatives

\section{Conclusions}

\section{Introduction}

Obesity can be defined as a chronic disease that is characterized by an excessive accumulation of adipose tissue. Once adipose tissue accumulates, a complex system of overlapping neuro-endocrine responses prevents it from diminishing. ${ }^{1}$ Obesity is caused by an imbalance between energy intake and expenditure, and is widely recognized as the largest and fastest growing public health problem. Its prevalence was first noted in adults, but this trend is also affecting children and adolescents, and it is predicted to increase by 2025 . Several factors are responsible for overweight and obesity, including genetic, metabolic, behavioral, and environmental influence. ${ }^{2,3}$

Traditionally, adipose tissue was considered as an inert energy depot, but now evidence is clear that adipocytes have a several different functions, closely controlled by neural and hormonal mechanisms, so they produce and release hormones and mediators in an autocrine, paracrine and endocrine manner. ${ }^{4}$ Obesity constitutes a pro-inflammatory state that eventually leads to serious health consequences and it is associated with an increased risk of morbidity, death, accelerated aging and it has been recently declared by the World Health 
Organization (WHO) as a global epidemy. The major co-morbidities include type 2 diabetes, metabolic syndrome, hypertension, dyslipidemia, myocardial infarction, stroke, some kinds of cancer, sleep apnea, and osteoarthritis. ${ }^{7}$ There is a strong relationship between body mass index (BMI) and risk of type 2 diabetes mellitus since both increase insulin secretion and insul in resistance result from obesity. ${ }^{8}$ Recent research has indicated that many common cancers, such as those of colon and kidney are also more prevalent among overweight individuals. Additional personal aspects like social acceptance, quality of life, and career trajectories are all compromised because of society discrimination against the obesity. ${ }^{3,9}$

\subsection{Pharmacological approach}

Since lifestyle changes in the form of dieting and/or exercise per se do not generally produce marked or sustainable weight loss and long-term success rates in the control of obesity in the clinicare low, no better than $10 \%$, intervention treatments like surgery and pharmacological are needed. ${ }^{10}$ Pharmacotherapy should be considered in overweight and obese patients with a BMI greater than $27 \mathrm{~kg} / \mathrm{m}^{2}$, particularly in the presence of co-morbidities such as type 2 diabetes or hypertension or an increased waist circumference, when conservative measures such as behavior therapy, diet, and exercise have not resulted in the desired weight loss. ${ }^{11}$ However, at the moment there is not a single effective medication and the ones that are currently used to promote weight loss are recommended only in highly selected patients on an individualized basis. ${ }^{12}$

Amphetamine derivatives were the first used as the earliest pharmacological agents for weight loss. However, due to serious adverse side effects they were discontinued. Three drugs had been approved by the Food and Drug Administration (FDA) for the treatment of obesity: the dual serotoninnorepinephrine reuptake inhibitor sibutramine (Meridia ${ }^{\circledR}$ and Reducti ${ }^{\circledR}$ ), lipase inhibitor orlistat (Xenical ${ }^{\circledR}$ and $\mathrm{Alli}^{\circledR}$ ) and cannabinoid-1 (CB-1) receptor antagonist rimonabant (Acomplia ${ }^{\circledR}$ ). Furthermore, recently sibutramine and rimonabant were suspended from the market because of cardiovascular side effects and psychiatric problems reported, respectively. Accordingly, there is a tremendous opportunity in the field of drug discovery and development for drugs in the treatment of obesity.

\subsection{Drug targets for obesity}

The hypothalamus, with its central importance in the regulation of energy homeostasis, has led to the discovery of target neuropeptides and their receptors in the search for weight loss therapies. ${ }^{13}$ Identified orexigenic molecules are: Agoutirelated peptide (AGRP), hypocretins, galanin, noradrenaline, melanin-concentrating hormone (MCH), neuropeptide Y (NPY). The anorexigenic molecules are the melanocortin, tirotropin released hormone (TRH), cocaineand amphetamine-regulated transcript (CART) and interleukin-1 beta, as well as other molecules like oxytocin, urocortin, glucagon-like peptide 1 , serotonin, and neurotensin. With all this, numerous other targets for the development of anti-obesity drugs had been identified within and outside the central nervous system. Examples include the alpha melanocite stimulant receptor, cannabinoid receptor (CB1); the $5-\mathrm{HT}_{2} \mathrm{C}$ receptor, and the receptor for melaninconcentrating hormone (MCH-R1). ${ }^{14}$

\section{Melanin-concentrating hormone (MCH)}

$\mathrm{MCH}$ is a nonadecapeptide, which was characterized as a circular factor mediating color change in teleost fish. ${ }^{15,16}$ Initially, the distribution of $\mathrm{MCH}$ in mammalian brains suggested that it might be involved in mediating "feeding behavior and energy balance". These data were confirmed when it 
was found that intracerebroventricular (ICV) administration of $5 \mu \mathrm{g}$ of $\mathrm{MCH}$ to rats led to a rapid increase in chow consumption. ${ }^{17}$ As an orexigenic peptide, $\mathrm{MCH}$ interacts with other neuropeptides that influence feeding behavior as NPY, neurotensin, among others. Additional effects of $\mathrm{MCH}$ in vivo in mice are stimulated water intake independent of food intake. $^{18,19}$

MCH-R1 was identified simultaneously by several groups, is a G-protein-coupled receptor with 353 aminoacids. ${ }^{20-22} \mathrm{MCH}-\mathrm{R} 1$ is highly expressed in the brain with a different expression in other tissues including muscle, eye and adipose tissue. ${ }^{23}$ To demonstrate the importance of the receptor, $\mathrm{MCH}-\mathrm{R} 1$ was inactivated in mice by homologous recombination. ${ }^{24,25}$ Mice lacking functional $\mathrm{MCH}-\mathrm{R} 1$ and maintained on a regular chow diet exhibited decreased fat mass, increased activity and were surprisingly found to be hyperphagic compared with their wildtype (wt) littermates. When placed on a high-fat diet, MCH-R1 deficient mice gained significantly less weight, suggesting that inactivation of $\mathrm{MCH}-\mathrm{R} 1$ protected them from diet-induced obesity (DIO). Similarly, specific $\mathrm{MCH}-\mathrm{R} 1$ antagonists produced comparable effects. $^{26}$

Recently, results of Karlsson et al supported an involvement of the $\mathrm{MCH}$ system in the regulation of energy balance as well as addiction-like behaviors such as sucrose reward and seeking. Data show that MCH-R1 antagonists decreased operant responding for sucrose but not saccharin, and reduced food intake more than sucrose, suggesting that $\mathrm{MCH}$ system may play a stronger role in caloric rather than reward processes. ${ }^{27}$

Additionally, a study showed that acute central administration of the specific MCH-R1 antagonists TPI 1361-17 exerted potent anxiolytic effects in two of the most common and accepted anxiety behavioral. This indicates that its anxiolytic effects are caused by blockade of $\mathrm{MCH}-\mathrm{R} 1$ alone. These results show that MCH-R1 is a viable target for the development of novel anxiolytic drugs. ${ }^{28}$
On the other hand, $\mathrm{MCH}-\mathrm{R} 2$ is 340 aminoacids long and its gene resides on the long arm of chromosome $6 .{ }^{29,30}$ The overall homology between the two $\mathrm{MCH}$ receptors is quite low. They share only $38 \%$ identical amino acids with the highest homology in the transmembrane domains that form part of the putative $\mathrm{MCH}$-binding pocket. $\mathrm{MCH}-\mathrm{R} 2$ does not appear to be present in many species. ${ }^{31}$ Whereby, the functional importance of $\mathrm{MCH}-\mathrm{R} 2$ is currently difficult to assess without an appropriate animal model.

\section{MCH-R1 Antagonists}

\subsection{Peptide derivatives}

In the last decade, early reports regarding the development of $\mathrm{MCH}-\mathrm{R} 1$ antagonists described peptidic compounds that attenuated orexigenic effects of the agonists. In the beginning of the study of antagonist peptides, Bednarek et al. determined structural features of human $\mathrm{MCH}$ that are crucial for interactions of this peptide hormone with $\mathrm{MCH}$ receptors. On the other hand, initially, Audinot et al. reported peptide analogues of $\mathrm{MCH}$ with a $\mathrm{K}_{\mathrm{b}}$ of 0.1$0.2 \mu \mathrm{M}$ and later through a molecular study. A potent and new MCH-R1 antagonist, denominated $S 38151$ with $a K_{b}$ of $4.3 \mathrm{nM}$ was described, which antagonizes food intake when injected ICV in the rat. ${ }^{32,33}$ Bednarek et al. showed a peptide $\mathrm{MCH}-\mathrm{R} 1$ antagonist with a half maximal inhibitory concentration $\left(\mathrm{IC}_{50}\right)$ of $14 \mathrm{nM}$ and $\mathrm{a} \mathrm{K}_{\mathrm{b}}$ of $0.9 \mathrm{nM} .{ }^{34}$ Nevertheless, at the present time, efforts to research peptide $\mathrm{MCH}-\mathrm{R} 1$ antagonists are low.

\subsection{Carboxamide derivatives}

The first small molecule orally active and selective $\mathrm{MCH}-\mathrm{R} 1$ antagonist was denominated T-226296 (Figure 1), which presented an $\mathrm{IC}_{50}$ of $5.5 \mathrm{nM}$, for the human 
receptor. Oral administration in rats at a dose of $30 \mathrm{mg} / \mathrm{Kg}$ of such compound produces a complete suppression of food intake induced by the administration of $\mathrm{MCH}$, which showed a good passage through the blood-brain barrier (BBB). ${ }^{35}$<smiles>[Y6][R6]([R6])(=O)O[Na]</smiles>

Figure 1. Compound T-226296, MCH-R1 antagonist

Initially, studies of molecular modeling of first MCH-R1 antagonists T-226296 and compounds of Argenta group, defined the following characteristics as being essential to $\mathrm{MCH}-\mathrm{R} 1$ binding: positive nitrogen, hydrogen acceptor group and the presence of one or two hydrophobic subunits. ${ }^{36}$ Recently, quantitative structure-activity relationship (QSAR) information derived from aproximately 300 benzamides compounds to contruct pharmacophore models suggests similar results of previous studies: a hydrophobic and an aromatic moieties, a hydrogen bond acceptor or donor and a positive charged site. $^{37}$

On the other hand, a second small molecule $\mathrm{MCH}-\mathrm{R} 1$ antagonist was identified, denominated SNAP-7941 (Figure 2), with a $\mathrm{K}_{\mathrm{b}}$ of $0.3 \mathrm{nM}$. In early studies, Borowsky et al. found that acute treatment with SNAP-7941 declined appetite in rats, and chronic treatment caused a noticeable and maintained reduction of weight in the same model. Studies in vivo demonstrated that SNAP-7941 was able to inhibit the effects of the central administration of $\mathrm{MCH}$ and showed effect on food intake. In DIO rats SNAP-7941 produced an anorexigenic effect. As a final point, SNAP-7941 produced chronic blockade of $\mathrm{MCH}$ and a low initial reduction of body weight that continued until the end of treatment. ${ }^{38}$

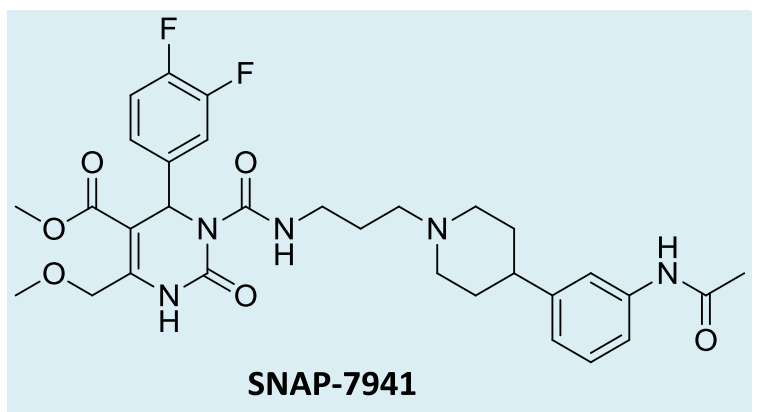

Figure 2. Compound SNAP-7941

Continued with the development of small molecules as $\mathrm{MCH}-\mathrm{R} 1$ antagonists, Witty et al. discovered the compound SB-568849 (Figure 3) with a $\mathrm{K}_{\mathrm{i}}$ of $7.7 \mathrm{nM}$, which showed good aqueous solubility, good BBB ratio and a positive pharmacokinetic profile with high oral bioavailability $(80 \%)$ in rats. ${ }^{39}$ However, analogous compound $\mathbf{1}$ (Figure $\mathbf{3}$ ) was identified as a potent human ether-a-go-gorelated gene ( $h E R G) \mathrm{K}^{+}$channel blocker in an in vitro patch-clamp study. This could be explained by two common structural elements: a positively charged group and at least one distal aromatic/lipophilic region. 
Whereby Kasai et al. suggested five effective methods for reducing the $\mathrm{hERG} \mathrm{K}^{+}$channel binding affinity: a) introduction of a bulky and/or hydrophilic moiety near terminal amine group; $b$ ) introduction of an $\mathrm{sp}^{2}$ bond on the assymetric carbon; c) removal of the nitrogen atom from the quinoline core; $d$ ) reversal of the amide bond from $\mathrm{CONH}$ to
NHCO; e) replacement of the terminal cyclopropylmethyl group with a bulkyl and /or hydrophilic substituent. Following these approaches, they found compound $\mathbf{2}$ (Figure 3), an orally bioavailable $\mathrm{MCH}-\mathrm{R} 1$ antagonists that showed excellent in vivo efficacy in a DIO rat model while maintaining a safety profile with respect to QTc prolongation. ${ }^{40}$<smiles>CCN(CC)CCOc1ccc(N(C)C(=O)c2ccc(-c3ccc(C(F)(F)F)cc3)cc2)cc1OC</smiles>

Figure 3. Compounds SB-568849, 1 and 2, carboxamide derivatives as MCH-R1 antagonists

An alternative design strategy proposed an incorporation of a thieno[3,2-d]pyrimidin$4(3 \mathrm{H})$-one ring that served to lock the amide conformation led to the discovery of compound GW-3430 (Figure 4) with an $\mathrm{IC}_{50}$ of $9.3 \mathrm{nM}$. Structure-activity relationship (SAR) showed that potency enhanced when the para-biphenyl amide group was substituted chlorophenylthienopyrimidinone. GW-3430 is a $\mathrm{MCH}-\mathrm{R} 1$ antagonist orally active that caused a significant and dose-dependent weight loss of $13.3 \%$ in obese AKR mice over a 12-day period at a dose of $3 \mathrm{mg} / \mathrm{kg}$. GlaxoSmithKline reported Phase I clinical trials of thieno[3,2-d]pyrimidin-4(3H)-one derivatives as MCH-R1 antagonist, but, studies has been discontinued. ${ }^{41,42}$

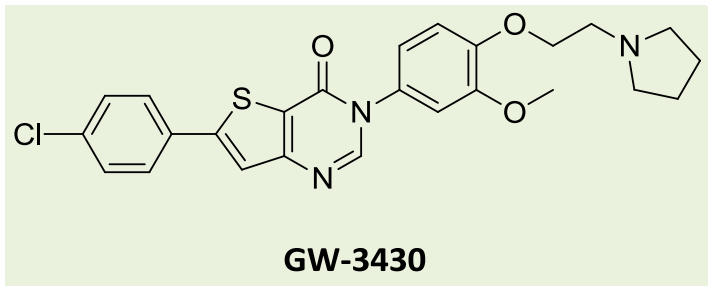

Figure 4. Compound GW-3430, a MCH-R1 antagonist orally active

Following with SAR studies, Tavares et al. established that the 4- and 6-position of the thieno[3,2.d]pyrimidin moiety was potency enhancing and suggested that analogues must present basic substituents and a neutral hydroxyl on the heterocyclic subunit. Also, they explored replacements of the quinoline moiety for generating potent and selective $\mathrm{MCH}-\mathrm{R} 1$ antagonists. They found naphtalene as well as other heterocyclic to be good 
substituents. These aromatic or heterocyclic moieties require the same substituents (basic nitrogen and hydroxyl group). One of the best is compound $\mathbf{3}$ (Figure 5), which during a 21 day treatment of oral administration at 1 , 3 and $10 \mathrm{mg} / \mathrm{kg}$ once daily caused a dosedependent weight loss of $-1.1,-3.2$ and $11.8 \%$, respectively. In the same study, rimonabant caused $-8.4 \%$ weight loss from pre-treatment body weight values $(48.6 \pm 0.9$ g, $n=33) \cdot{ }^{43}$ Recently, rimonabant was discontinued from clinical use due increased incidence of depression. However, studies reported administration of rimonabant in combination with MCH-R1 antagonist SNAP94847. This combination produced a dosedependent reduction in food intake at the 2 and $24 \mathrm{~h}$ measurement intervals. In addition, leads to a shift in markers of thermogenesis in BAT and lipid metabolism in WAT in directions consistent with reduced energy expenditure and increased lipolysis; produced a transient reduction in food intake, significantly reduced the fat mass, and adipocye cell size. Importantly, depression caused by rimonabant was significantly attenuated by $\mathrm{MCH}-\mathrm{R} 1$ antagonist in the forced swim test. ${ }^{44}$

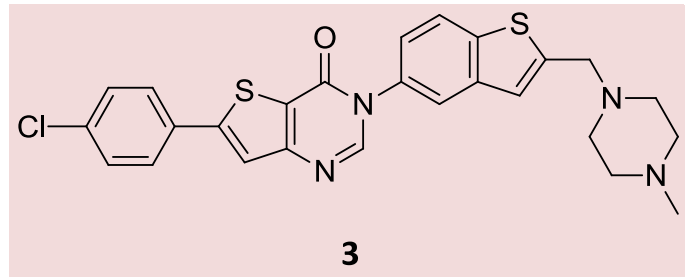

Figure 5. Compound 3, a thieno[3,2.d]pyrimidine derivative as $\mathrm{MCH}-\mathrm{R} 1$ antagonist

Later, a research group identified a new class of thieno[3,2-d]pyrimidin-4(3H)-one $\mathrm{MCH}-\mathrm{R} 1$ antagonists with incorporation of benzimidazole group on the thienopyrimidinone ring (compound 4, Figure
6), and explored the SAR of these compounds. Interestingly, results showed how the regioisomeric substitution on the benzimidazole ring would affect both potency and bioavailability. ${ }^{45}$

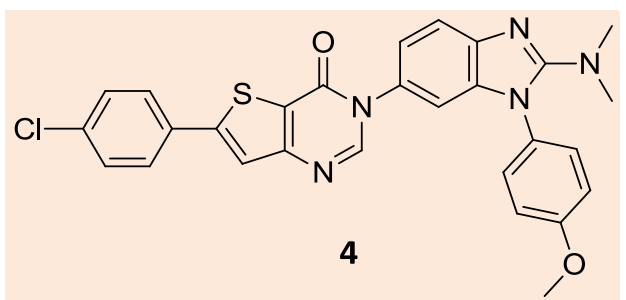

Figure 6. Compound 4, a thieno[3,2.d]pyrimidine derivative

Initially, Huang et al. reported compounds derived from aminoaryl substituted 3aminopyrrolidine as the central moiety and biphenyl carboxamidegroup. One of the best was compound 5 (Figure 7) with a $\mathrm{K}_{\mathrm{i}}$ of 2.3 $\mathrm{nM}$, which had good oral bioavailability (32\%) and in vivo efficacy in rats (anorectic effects). 


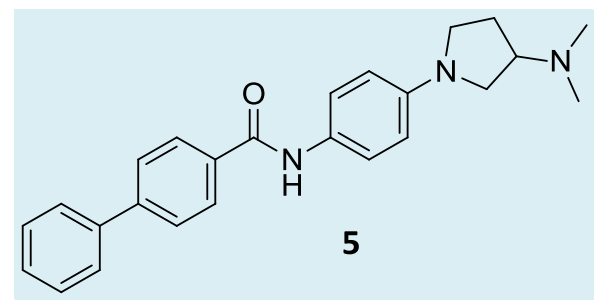

Figure 7. Compound 5, a substituted 3-aminopyrrolidine derivative

A serious problem from series of 3aminopyrrolidine derivatives was high clearance in rats. ${ }^{46}$ Thus, modification of the benzamide group in bicyclic derivatives retaining a carbonyl group, was proposed as an effective strategy for minimizing clearance of the compounds. ${ }^{47}$ However, in the case of the fused benzopyridazinones ring as compound 6 (Figure 8), the improved pharmacokinetics was also associated with some untoward partitioning of the compound into tissues and very high brain penetration. ${ }^{48}$ Later, they showed a series of substituted chromones (compound 7, Figure 8) with subnanomolar binding affinity and $66 \%$ oral bioavailability in rats. Interestingly, they discovered that a methoxyl group at 4position on phenyl ring was apparently responsible for the very rapid human liver chromosome (HLM) clearance. ${ }^{49}$
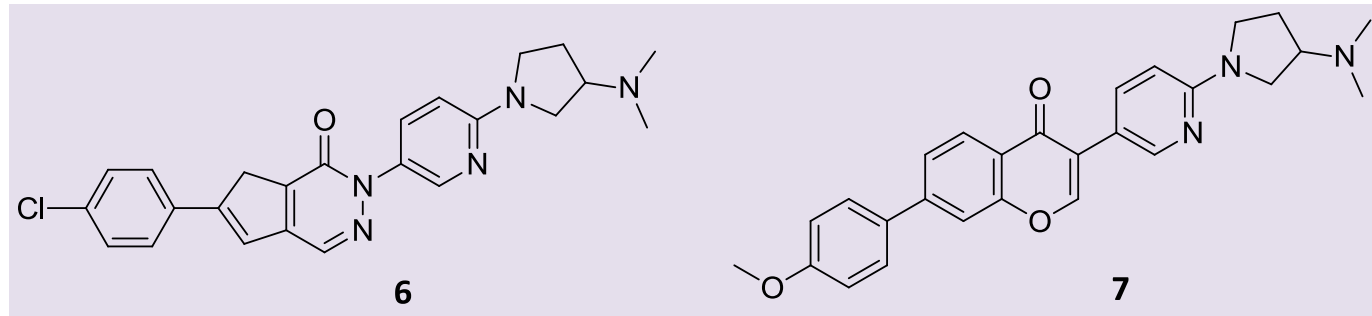

Figure 8. Compound 6 and 7, bicyclic derivatives with a carbonyl group

Schwarz et al. analyzed compound 8 (Figure 9), structurally similar to 3aminopyrrolidine, differing only in substitutions on the para position of the phenyl and pyrimidinone ring with a chlorine atom or a trifluoromethyl group with a $\mathrm{K}_{\mathrm{i}}$ of $7.3 \pm 2.9 \mathrm{nM}$ and $1.1 \pm 0.6 \mathrm{nM}$, respectively. Interestingly, their abilities to inhibit $\mathrm{Ca}^{2+}$ mobilization as a function of time were markedly influenced by the para-benzene substitutions. Therefore, it was probable due to the presence of either chlorine or trifluromethyl introduces, both a steric bulk substituent, as well as redistribution of electron density. Results showed that steric interference between the receptor and substituted compounds was a key factor influencing the inhibitory potential. ${ }^{50}$<smiles>CN(C)C1CCN(c2ccc(-n3ncc4cc(-c5ccc(C(F)(F)F)cc5)ccc4c3=O)cn2)C1</smiles>

Figure 9. Compound 8, a 3-aminopyrrolidine derivative 
Otherwise, Mendez-Andino et al. discovered a novel class of potent $\mathrm{MCH}-\mathrm{R} 1$ antagonists; their design was structure-based on biphenyl carboxy group replacements suggesting key pharmacophoric points (a tertiary amine, an amide bond and a terminal aromatic ring of the biphenyl group) for biological activity. ${ }^{47}$ Compound $\mathbf{9}$ (Figure 10 ) showed its potential as an effective orally dosed $\mathrm{MCH}-\mathrm{R} 1$ antagonist. Unfortunately, compound 9 was compromised by its hERG blockage activity, leading to an observed dose-dependent increase in QT interval in anesthetized dogs at serum concentrations comparable to those obtained at efficacious doses. Similar ketopiperazine derivative (compound 10, Figure 10) did not promote any weight loss in a DIO mouse study and the researchers hypothesized that it had no in vivo activity probably due to insufficient brain exposure because the hydrophilic nature of the compound could have contributed to its inability to effectively cross the BBB. ${ }^{51}$

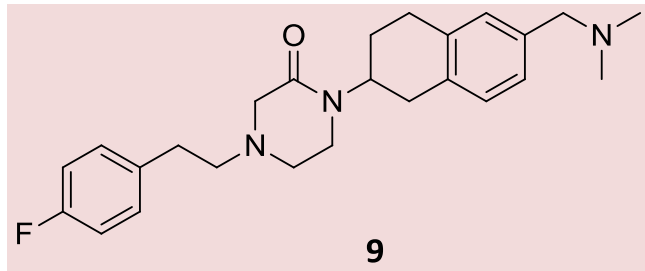

Figure 10. Compounds 9 and 10, ketopiperazine derivatives as MCH-R1 antagonists
Meyers et al. designed biphenyl carboxamide derivatives with aminomethyl tetrahydronaphthalene moiety as potent $\mathrm{MCH}-\mathrm{R} 1$ antagonists. Results showed that compound $\mathbf{1 1}$ (Figure 11), with an $\mathrm{IC}_{50}$ of 1.8 $\mu \mathrm{M}$, had potent hERG ion channel activity, compromising it. ${ }^{52}$ Thus, its design is marked by the introduction of nitrogen in the terminal aromatic ring, what declined hERG activity significantly. It was also incorporated polar functionality proximal to tertiary amine to reduce hERG binding. ${ }^{53}$ Unfortunately, substitutions did not have as dramatic an effect as in biphenyl substitutions, but compounds did not bind to $5-\mathrm{HT}_{2 \mathrm{C}}$ (related with adverse effects as anxiety, mood and others), suggesting that incorporation of polar functionality proximal to the benzylic tertiary amine helps to decrease $5-\mathrm{HT}_{2 \mathrm{C}}$ activity. $^{54}$<smiles>CN(C)Cc1ccc2c(c1)CC[C@@H](N(C)C(=O)c1ccc(-c3ccc(F)cc3)cc1)C2</smiles>

Figure 11. Compound 11, with aminomethyl tetrahydronaphthalene moiety

Later, Meyers et al. developed derivatives of aminomethyl tetrahidronaphtphalene ketopiperazine to discover compounds with greater selectivity over hERG through substitutions at the para-fluorophenyl and benzylic tertiary amine. In addition, they determined the relationship between amine basicity and hERG activity and showed that an imidazole analog was a more potent hERG blocker despite being less basic than tertiary amine. Compound $\mathbf{1 2}$ (Figure 12) proved to have the best profile, with $\mathrm{MCH}-\mathrm{R} 1 \mathrm{~K}_{\mathrm{i}}$ of 16 $\mathrm{nM}$ and hERG IC ${ }_{50}$ of $25 \mu \mathrm{M}$. $^{55}$ 


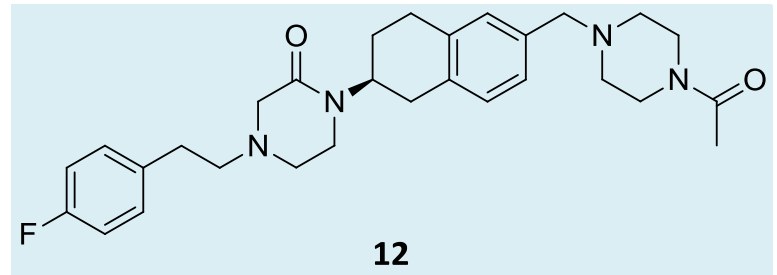

Figure 12. Compound 12, a tetrahidronaphtphalene ketopiperazine derivative

A research group disclosed the 5(pyridinin-1-yl)indazole (compound 13, Figure 13) as a potent $\mathrm{MCH}-\mathrm{R} 1$ antagonist that showed a statistically significant reduction in body weight (2.8\%) at $60 \mathrm{mg} / \mathrm{Kg}$ (qd) dose. However, pharmacokinetic profile was inconsistent. Therefore, they established as design strategy to introduce a conformacional constraint between the indazole ring and the basic amine, finding compound 13a (Figure 13) that showed a highly significative reduction in body weight (7.2\%) at a once-daily $30 \mathrm{mg} / \mathrm{Kg}$ dose and compound 13b (Figure 13) that induced a slightly greater effect, producing a $9.1 \%$ reduction in body weight after dosign at 30 $\mathrm{mg} / \mathrm{kg}$. Both results is favorably compared to compound $13 .{ }^{56}$ A serious problem of $\mathrm{MCH}-$ R1 antagonists is the cardiovascular risk. Guzzo's group continued with efforts on a series of 5-(pyridinon-1-yl)indazoles as $\mathrm{MCH}$ R1 antagonists aiming a reduction in the interaction with the $h E R G$ potassium channel. They found that adjustments to a pendant amine group could be used to attenuate hERG binding. SAR studies indicated that interaction with the hERG channel could be reduced through the incorporation of a hydroxyl group in a position $\beta$ to the basic amine (compound 13c, Figure 13). Additionally, conversion of the hydroxyl moiety to a methoxy group decreased or eliminated the positive effect on $\mathrm{hERG}{ }^{57}$<smiles>O=c1cc(OCc2ccccc2)ccn1-c1ccc2c(cnn2CCN2CCCC2)c1</smiles>

13<smiles>CN1CCc2c(n(C)c3cc(-n4ccc(OCc5ccccc5)cc4=O)ccc23)C1</smiles>

$13 b$<smiles>CN1CCc2c(c3ccc(-n4ccc(OCc5ccccc5)cc4=O)cc3n2C)C1</smiles>

$13 a$<smiles>CN(C)CC(O)Cn1ncc2cc(-n3ccc(OCc4ccccc4)cc3=O)ccc21</smiles>

Figure 13. Structure of 5-(pyridinin-1-yl)indazole derivatives as $\mathrm{MCH}-\mathrm{R} 1$ antagonists

Kym et al. identified the MCH-R1 antagonists aminopiperidinecoumarin by high throughput screening (HTS) with an $I_{50}$ of $191 \pm 40$ nM. SAR study rapidly identified C6 substitution on coumarin as being critical for improvement in $\mathrm{MCH}-\mathrm{R} 1$ affinity and 
functional antagonism (efficient penetration into the brain upon oral dosing at $10 \mathrm{mg} / \mathrm{Kg}$ ). Compound 14 (Figure 14) provided the best combination of potent functional antagonism, metabolic stability and exposure in the brain with an area under the curve (AUC) of $4.17 \mu \mathrm{g} . \mathrm{h} / \mathrm{g}$ with oral dosing at 10 $\mathrm{mg} / \mathrm{kg}$ in DIO mice. The researchers also observed cardiovascular toxicity at low micromolar concentration in the anesthetized dog assay raising significant concern. Interestingly, the observed cardiotoxicity was linked to the particular structural chemotype and not to $\mathrm{MCH}-\mathrm{R} 1$ activity. ${ }^{58}$<smiles>O=c1cc(NC2CCN(Cc3ccc4c(c3)OCO4)CC2)c2cc(Cl)ccc2o1</smiles>

Figure 14. Compound 14, shows cardiovascular toxicity

Further, optimization of coumarin derivative led to the discovery of chromone2-carboxamide (compound 15, Figure 15) which was orally efficacious in a DIO mouse model, retaining a favorable cardiovascular profile in rat and showing dramatic improvement in effects on arterial pressure in a dog cardiovascular model. In terms of cardiovascular safety in rat, the chromone amide has emerged as the best heterocycle from a set of 4-aminopiperidines. However, this analogue also led to prolongation of the QT interval in dog. ${ }^{59}$

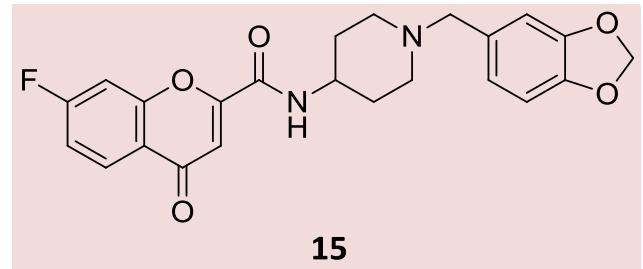

Figure 15. Compound 15, a chromone-2-carboxamide derivative

Grey et al. discovered the compound $\mathbf{1 6}$ (Figure 16). ${ }^{60}$ SAR, showed that modifying the biphenyl carboxamide group, with replacement of the phenyl ring with other linkers, led to less potent analogs. Introduction of a urea functional group to replace the carboxamide group led to a threefold drop in potency. ${ }^{61}$ Huang et al. determined that ureas were a few folds less potent than the similar amides; the introduction of a thiophene replacement of the phenyl ring produced the most potent compounds. Notwithstanding, the same group attempted to replace the phenyl ring bonded to the amide nitrogen with saturated heterocycles, such as piperidine and piperazine. The heterocyclic-substituted derivatives resulted in very low or total loss of receptor affinity. These results suggested that the phenyl group is one of the key interaction sites with $\mathrm{MCH}-\mathrm{R} 1$, while the arylcarboxamide could serve as a linker to control the orientation of the phenyl and as a lipophilic site to interact with the receptor. On the other side, a basic amine, was required to give high potency, although substitution on the basic amine was not crucial for binding (compound 17, Figure 16). ${ }^{46}$ In addition, Grey et al. confirmed that the stereochemistry of the pyrrolidine ring 
residing closer to the carboxamide group is more critical for high affinity binding than the anal ogous center. For example, compound 16 (Figure 16) showed functional activity with an $\mathrm{IC}_{50}$ of $14 \mathrm{nM}$. Nevertheless, it was rapidly metabolized in an in vitro HLM assay with an intrinsic clearance of $50 \mathrm{~mL} / \mathrm{min} / \mathrm{kg}$, suggesting that it would be rapidly cleared in vivo. ${ }^{60}$<smiles>CN(C)C1CCN(c2ccc(NC(=O)c3ccc(-c4ccccc4)cc3)cc2)C1</smiles><smiles>CN(C(=O)c1ccc(-c2ccc(C(F)(F)F)cc2)cc1)C1CCN(C(=O)N(C)C2CCN(CCCc3ccc(Cl)cc3)C2)C1</smiles>

Figure 16. Compounds 16 and 17

Previous urea derivatives $\mathrm{MCH}-\mathrm{R} 1$ antagonists exhibited low metabolic stability in an in vitro HLM assay and had only moderate oral exposure in rat. ${ }^{62}$ Hudson et al. identified two problems: significant CYP2D6 inhibition and low brain penetration. ${ }^{63}$ Thus, Rowbotton et al. explored particular changes around the biarylcarboxamide moiety and showed antagonists based on an $\mathrm{N}$-methylated bisaminopyrrolidine urea, containing a 5-phenyl2-thiophenecarboxamide group (compound 18, Figure 17) that display promising in vitro metabolic stability profiles exhibiting good stability in the HLM assay with no significant inhibition of key CYP450 metabolizing enzymes. ${ }^{64}$

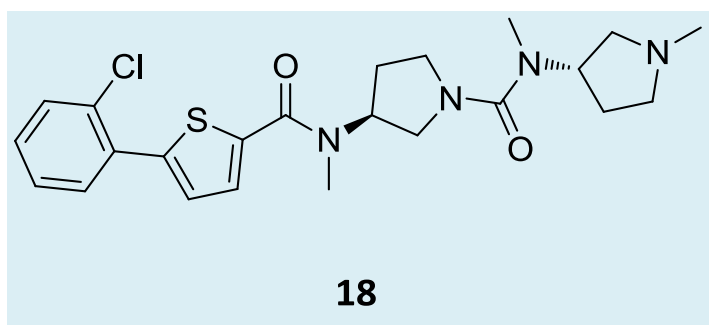

Figure 17. Compound 18, a urea derivative

Palani et al. developed a series of urea derivatives as $\mathrm{MCH}-\mathrm{R} 1$ antagonists, through screening identifying biaryl ureas as potent antagonists for the treatment of obesity. One of its compounds was a potent MCH-R1 antagonist with a $\mathrm{K}_{\mathrm{i}}$ of $3.9 \mathrm{nM}$. SAR study determined that $\mathrm{N}$-methylation of the urea resulted in a significant drop in affinity and meta substitution at the distal ring of the biaryl was preferred over the ortho and para positions, and the cyano group was found to be the best meta substituent. However, some compounds exhibited potent $5-\mathrm{HT}$ reuptake transporter inhibition with a $\mathrm{K}_{\mathrm{i}}$ of $27 \pm 2 \mathrm{nM}$. Since SAR studies of pyrrolidine analogues resulted in the identification of compound $\mathbf{1 9}$ (Figure 18), which showed an excellent profile in terms of $\mathrm{MCH}-\mathrm{R} 1$ affinity and selectivity over other neurotransmitter receptors involved in food intake with oral rat plasma levels, including good brain levels $(579 \mathrm{ng} / \mathrm{g})$ at $6 \mathrm{~h}$. 
Rivera, G. et al.

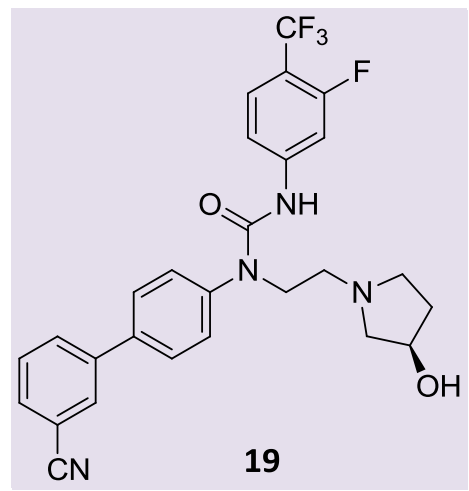

Figure 18. Compound 19, a urea derivative

Compound 19 showed excellent in vitro and moderate in vivo activity, and was orally efficacious when administered during 28 day in rodent obesity model, showing a decrease in food intake and weight gain beyond a selective decrease in fat mass relative to lean mass. However, studies were discontinued due to the presence of a highly mutagenic Ames positive biarylaniline subunit. ${ }^{65}$
Posteriorly, McBriar et al. explored modification of the phenyl ring and discovered a bicycloalkyl urea $\mathrm{MCH}-\mathrm{R} 1$ antagonist (compound 20, Figure 19). They mentioned that the trans isomer was much more active than the cis isomer and suggested a bycyclohexane moiety as a successful aryl ring surrogate. ${ }^{66}$

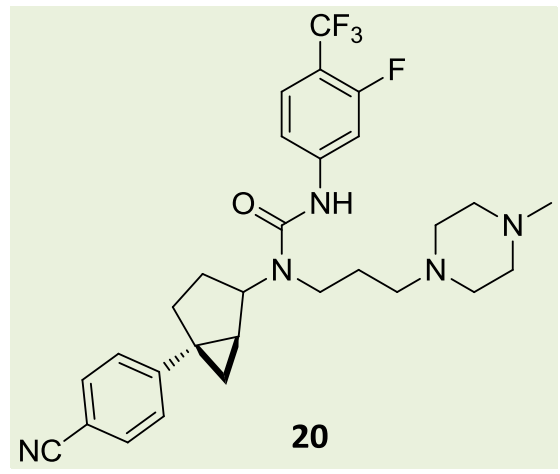

Figure 19. Compound 20, a urea derivative

Palani et al. reported a different approach modifying the biaryl aniline moiety which resulted in the discovery of biaryl diamides as potent MCH-R1 antagonists (compound 21, Figure 20). It was proposed that the considerable loss of activity with biaryl methylene series could be due to changes in the orientation of the biaryl as well as the hydrogen binding interactions provided by urea $\mathrm{N}-\mathrm{H}$ with the receptor. ${ }^{67}$ 


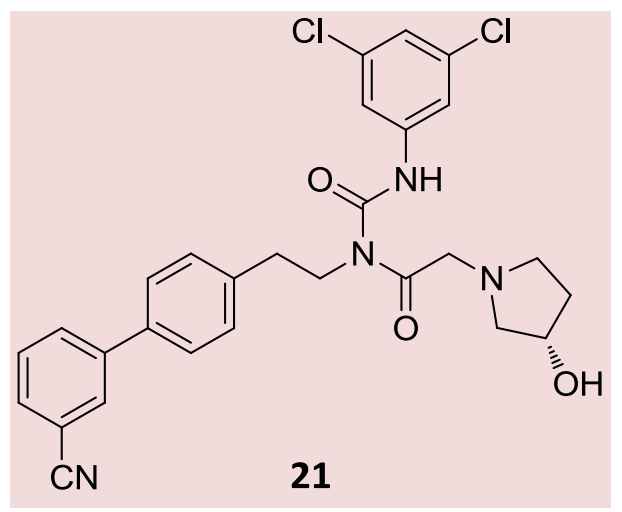

Figure 20. Compound 21, a biaryl diamide as potent $\mathrm{MCH}-\mathrm{R} 1$ antagonists

In other study, Sasikumar et al. investigated the use of urea isosteres, such as aminobenzimidazoles, which share key pharmacophores. They noted that all of the new aminobenzimidazole compounds were inactive in a similar $\mathrm{MCH}-\mathrm{R} 2$ binding assay, proposing high subtype selectivity. It was made $\mathrm{N}$-alkylation of benzimidazole nitrogen and obtained substantially less active compounds indicating that the benzimidazole $\mathrm{N}-\mathrm{H}$ plays a key role in inhibitor binding to the MCH-R1 receptor, and showed compound 22 (Figure 21) with $>80 \%$ receptor occupancy in mouse at $6 \mathrm{~h}$ and some with $>50 \%$ receptor occupancy after $24 \mathrm{~h}^{68}$

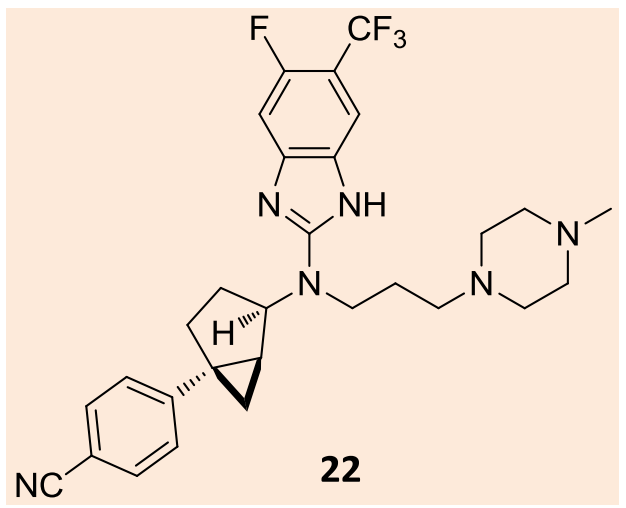

Figure 21. Compound 22, a benzimidazole derivative

Ma et al. reported compounds derived from biarylether as MCH-R1 antagonists. Based on their results, several observations were made: a tertiary amine was preferred over a primary amine, the presence of a tertiary amine is common to $\mathrm{MCH}-\mathrm{R} 1$ antagonists and accounts for a key salt bridge interaction with the receptor suggesting that the urea $\mathrm{N}-\mathrm{H}$ is involved in key hydrogen bonding interaction with the MCH-R1 receptor. $\mathrm{Ma}$ et al. discovered the denominated AMGN-608450 (Figure 22), which presents an $I C_{50}$ of $1.0 \mathrm{nM}$, a half-life of 1.5 hours and $a C_{\max }$ in the brain of 31.5 $\mathrm{ng} / \mathrm{g}{ }^{69,70}$ 


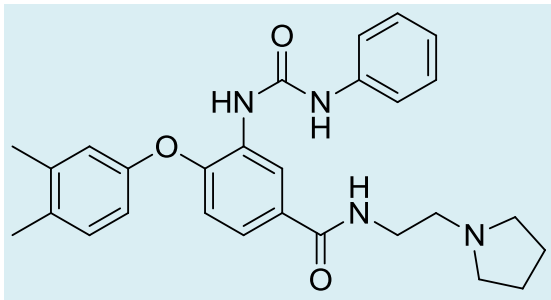

AMGN-608450

Figure 22. Compound AMGN-608450, a biarylether as MCH-R1 antagonists

Monge's group made molecular modeling and docking studies of two new urea derivatives series of $\mathrm{MCH}-\mathrm{R} 1$ antagonists. Interestingly, they established the following conclusions: a) the biphenylgroup binds in an aromatic cage formed by residues of phenylalanine and tyrosine; b) the basic amine is involved in an ionic interaction with Asp3.32; c) the flexibility of the chain joining the two former scaffolds must be enough to allow a good binding of both them; d) the hydroxyl group and the urea hydrogen atom present are predicted to bind residue GIn5.42. In general, they suggest that the presence of small polar group in the antagonists capable of binding Gln5.42 and/or Gln6.55 appears to be important for their activity as $\mathrm{MCH}-\mathrm{R} 1$ antagonist. ${ }^{71}$
Vasudevan et al. discovered quinoline scaffold for the development of MCH-R1 antagonists, they reported a compound derived from 2-amino-8-alkoxy quinolines, denominated A-224940 (Figure 23) with an $\mathrm{IC}_{50}$ of $91 \mathrm{nM}$. Their continuing efforts to transform this compound into a potent and orally active $\mathrm{MCH}-\mathrm{R} 1$ antagonist suggest that retaining the basic nitrogen in the side chain was found to have more efficient BBB penetration and half-life parameters and extending the aliphatic hydrophobic substituent by one carbon tether is slightly detrimental to $\mathrm{MCH}-\mathrm{R} 1$ binding affinity. Structural modulations of A-224940 allowed them to obtain compound 23 (Figure 23), that presented an $\mathrm{IC}_{50}$ of $3.0 \mathrm{nM}$ and one AUC in brain of $11 \mathrm{ng} . \mathrm{hr} / \mathrm{mL}{ }^{72}$

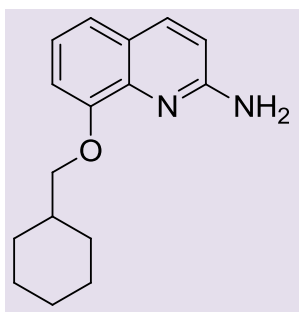

A-224940

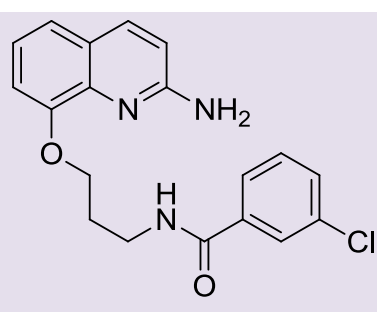

23

Figure 23. Compounds A224940 and 23, 2-amino-8-alkoxy quinolones as MCH-R1 antagonists

Ulven et al. corroborated through docking studies with potential ligands the need for a hydrophobic side as observed in compound T-226296. Studies suggested that Asp123 interacts preferentially with the nitrogen of the quinoline ring. They showed a 6acylamino-2-aminoquinoline (compound $\mathbf{2 4}$, Figure 24) antagonist with an $\mathrm{IC}_{50}$ of $1.9 \pm 0.4$ $\mathrm{nM}$, suggesting that the aromatic ring is coplanar with the quinoline system. The redundancy of the basic amine was also noted by the Argenta Group, although they found a piperidine analogue to be less potent, ${ }^{73}$ corroborating the idea that the electron donating property of the 2-amino group is more important that any specific direct interaction with the binding site. ${ }^{47}$ 


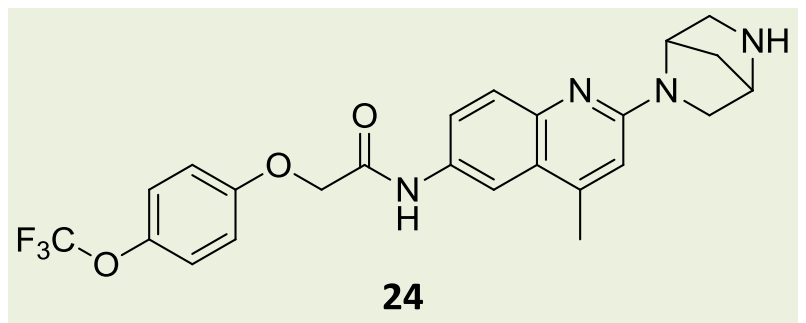

Figure 24. Compound 24, a 2-aminoquinoline derivative

Warshakoon et al. designed a novel series of substituted quinoline analogs (compound 25, Figure 25) in disclosed MCH-R1 antagonists which contained a basic amine group and two aromatic groups joined by an appropriate linker. In the aromatic region, the biaryl compounds exhibited potent binding to the $\mathrm{MCH}-\mathrm{R} 1$. Placing a heteroatom in the inner benzene of the biaryl ring system was detrimental to activity. They also obtained potent $\mathrm{MCH}$ activity as well as selectivity by placing polar, hydrogen bond accepting groups on the tertiary amine region and if the hydrogen of the amide nitrogen was replaced with a methyl group, a conformational restriction around amide bond to interact with receptors in a favourable fashion was obtained. ${ }^{74}$<smiles>[Z5]SCc1cccc2cc(CN(C)C)cnc12</smiles>

Figure 25. Compound 25 , a quinolone derivative with carboxamide moiety on the left hand

Compounds derived from 2- for good activity, since the change to an aminoquinolines were developed by Argenta aliphatic group at the terminus produces a Discovery. They showed compound $\mathbf{2 6}$ poorly active compound and a para (Figure 26) with an $\mathrm{IC}_{50}$ of $55.0 \mathrm{nM}$. SAR studies showed that the methyl/ethyl switch at basic nitrogen did not significantly affect activity and the methyl substitution in the linker of the amide had a detrimental effect. An aromatic group appeared to be necessary substituent in the terminal aromatic ring seems to be required for better potency. Lipophilic substituents, such as a chlorine atom, seems to give better potency than the more polar methoxy. ${ }^{69,75}$<smiles>Cc1cc(N2CCN(C)CC2)nc2ccc(NC(=O)COc3ccc(Cl)cc3)cc12</smiles>

Figure 26. Compound 26, a 2-aminoquinolines derivative 
A series of 4-(dimethylamino)quinazolines was designed by Kanuma et al. as potent and selective antagonists for $\mathrm{MCH}-\mathrm{R} 1$ with an $\mathrm{IC}_{50}$ of $100 \mathrm{nM}$. They identified compound AR129330 (Figure 27) by HTS of a G proteincoupled receptor (GPCR)-directed library using a functional assay with a constitutively activated form of the receptor. Their results indicated that both 4-amino-substitutions of the quinazoline and the terminal phenyl group are critical for $\mathrm{MCH}-\mathrm{R} 1$ activity and form two key parts of the MCH-R1 pharmacophore with the trans-1,4cyclohexane serving as linker between the two pharmacophoric groups. Changing the relative orientation of the substituents across the cyclohexyl ring of AR-129330 from trans to cis provided a compound which resulted with decreased activity. In addition, they proposed that the length and stereochemistry of the linker between the phenyl ring and the quinoxaline group are determining factors to affinity with $\mathrm{MCH}$ R1. ${ }^{76}$

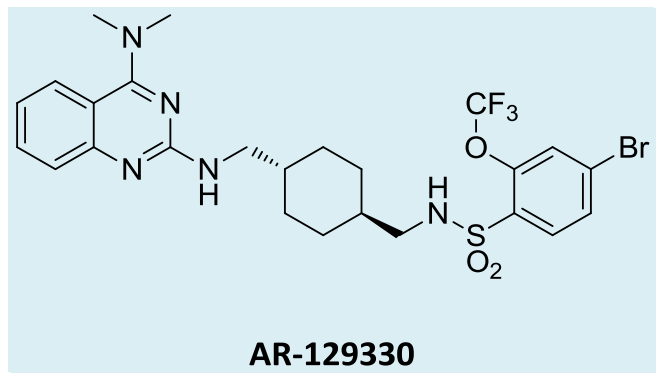

Figure 27. Compound AR-129330, a 4-(dimethylamino)quinazoline derivative

Kanuma et al., through a systematic optimization of the linker, aromatic subunit linked to the sulfonylamide of AR-129330, identified compound ATC-0175 (Figure 28), which displayed potent antagonist activity for $\mathrm{MCH}-\mathrm{R} 1$ with an $\mathrm{IC}_{50}$ of $2.4 \mathrm{nM}$. Importantly, the selectivity of ATC-0175 for the MCH-R1 over the $\mathrm{Y} 5$ and the $\alpha_{2 \mathrm{~A}}$ receptors represented a significant improvement over that of the initial AR-129330; it became clear that sulfonamide derivatives, in general, had a tendency to be less metabolically stable than the amide and the amine derivatives in rat and HLM assays. ${ }^{42}$

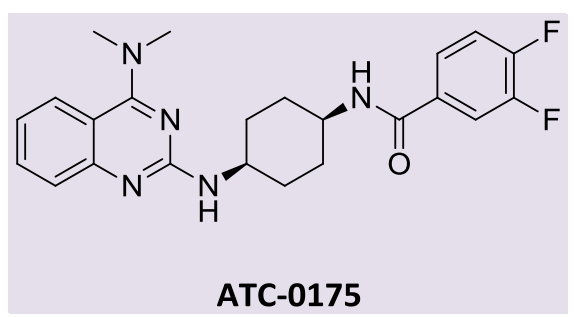

Figure 28. Compound ATC-0175, a quinazoline derivative

Later, efforts focused on finding the optimal distance between the two regions of the $\mathrm{MCH}-\mathrm{R} 1$ pharmacophore in the cis-4aminomethylcyclohexyl amine derivatives, suggesting that the distance of three atoms was the optimal length from the cyclohexane ring to the benzene ring. However, enhancement of metabolic stability with good $\mathrm{MCH}-\mathrm{R} 1$ antagonist activity was only possible by altering the position of the nitrogen atom. This optimization led to the discovery of compound ATC-0065 (Figure 29) as a metabolically stable $\mathrm{MCH}-\mathrm{R} 1$ antagonist. ${ }^{42}$ 


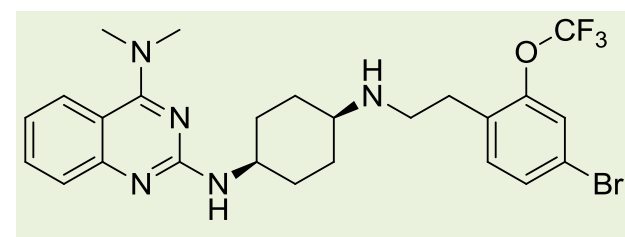

ATC-0065

Figure 29. Compound ATC-0065, a quinazoline derivative

Recently, Sasmal et al., described a new series of quinazoline derivated as $\mathrm{MCH}-\mathrm{R} 1$ antagonists. Based in SAR studies they reasoned that quinoline site could be involved in the hERG interaction, that has been an issue for several chemotypes and by modifying the basicity and introducing additional nitrogen could improve hERG liability as well as solubility by replacing the quinoline with a quinazoline system.
However, some quinozalines derivatives displayed considerably lower binding affinity than the corresponding quinoline analog in the SPA assay. In an extended SAR exploration, they described compound $\mathbf{2 7}$ (Figure 30) with good metabolic stability and reasonable stability in blood. Indeed, further optimization are needed to optimized compounds of this chemotype. ${ }^{77}$

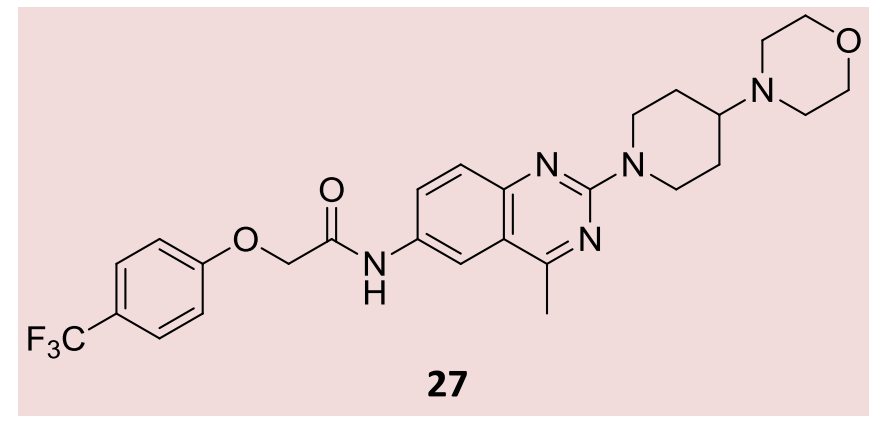

Figure 30. Compound 27, a new quinazoline derivative

Amgen utilizing a aequorin $\mathrm{MCH}-\mathrm{R} 1$ cellular assay measuring the blockade of intracellular $\mathrm{Ca}^{2+}$ mobilization caused by $\mathrm{MCH}$, resulted in the identification of compound 28 (Figure 31). Analog compound 29 (Figure 31) had the best potency with an $\mathrm{IC}_{50}$ of $0.5 \mathrm{nM}$ in the $\mathrm{MCH}-\mathrm{R} 1$ binding assay and an $\mathrm{IC}_{50}$ of $6 \mathrm{nM}$ in the $\mathrm{MCH}-\mathrm{R} 1$ aequorin assay. Pharmacokinetic profiles showed a low clearance in humans. At 1 and $5 \mathrm{mg} / \mathrm{kg}$ of compound 29, food intake was inhibited almost completely. Additionally, animal dosed with compound $\mathbf{2 9}$ showed no signs of toxicity. In summary this compound has good PK in several species and shows in vivo efficacy in both $\mathrm{MCH}$ cannulated rat model and the cynomologus monkey food consumption model. ${ }^{78}$ 
<smiles>CC1c2c([nH]c3ccccc23)CC2CCN(C)CC21</smiles>

28<smiles>C[C@H]1c2c([nH]c3ccc(C(F)(F)F)cc23)C[C@H]2CCN(CCCC3CCOCC3)C[C@H]21</smiles>

29

Figure 31. Compounds 28 and 29, an indole derivatives

Efforts in recent years in development $\mathrm{MCH}-\mathrm{R} 1$ antagonists have been low, due to insuitable PK profile and hERG binding activity. Recently, new 2-aryl substituted benzimidazoles derivatives, containing the alkylpiperidinylphenyl acetamide group at the 1-position, displayed highly potent binding affinity to MCH-R1. Results of SAR study determined that when the length of the linker is increased from $\mathrm{C} 3$ to $\mathrm{C} 4$ and $\mathrm{C} 5$, $\mathrm{MCH}-\mathrm{R} 1$ binding affinity is decreased. In addition, introduction of a chlorine atom at the para-aryl position and an acetanilide group at meta-position leads to excellent $\mathrm{MCH}-\mathrm{R} 1$ binding $\left(\mathrm{IC}_{50}=1 \mathrm{nM}\right.$, compound 30, Figure 32). Additionally, replacement of the anilide group by small substituents such as fluorine, methoxy and methyl resulted in a drop in binding affinity. These results indicate that the position and size of the anilide group might be critical for binding to $\mathrm{MCH}-\mathrm{R} 1$. However, data concerning problems related to $h E R G$ binding with this compound has not been reported. ${ }^{79}$

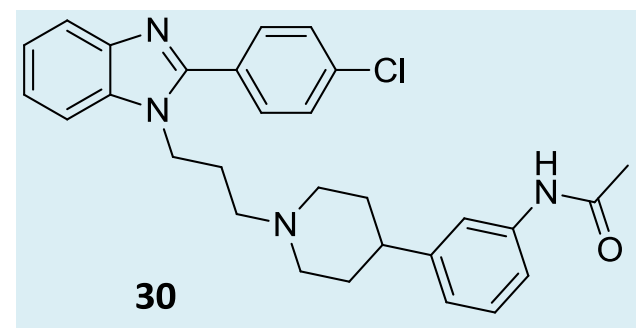

Figure 32. Compound 30 , a benzimidazole derivative

\section{Conclusions}

Obesity remains a serious health problem all over the world, and at this time there are no safe and efficient drugs for pharmacological treatment. MCH antagonists emerge as a promising alternative for obesity treatment. However, results of diverse research groups showed that $\mathrm{MCH}-\mathrm{R} 1$ antagonists, described until now, can only reach low concentrations in brain and plasma in in vivo studies. Regarding receptor affinity, aspects like stereochemistry, molecular shape and basicity of the tertiary nitrogen all seems to play important roles in the molecular recognition by the receptor. ${ }^{80}$
Additionally, important cardiovascular side effects (binding to the hERG potassium channel) have been recently observed in some MCH-R1 antagonists. Furthermore, design strategies still need to circumvent the hERG-binding, since this cause absorption, distribution, metabolism, and excretion limitations hindering the progression in the research of these compounds. Currently, only prodrug BMS-830216 has been tested in randomized, double-bind, placebo controlled trials. ${ }^{37}$ Therefore, some $\mathrm{MCH}-\mathrm{R} 1$ antagonist derivatives may be still a viable approach for pharmacological treatment of obesity. 


\section{References}

${ }^{1}$ Leibel, R. L. Nutr. Rev. 2002, 60, S15. [CrossRef] [PubMed]

2 Rodgers, R. J.; Tschöp, M. H.; Wilding, J. P. Dis. Model. Mech. 2012, 5, 621. [CrossRef] [PubMed]

${ }^{3}$ Roth, J.; Qiang, X.; Marbán, S. L.; Redelt, H.; Lowell, B. C. Obes. Res. 2004, 12, $88 \mathrm{~S}$. [PubMed]

${ }^{4}$ Hofbauer, K. G. Int. J. Obes. Relat. Metab. Disord. 2002, 26, S18. [CrossRef] [PubMed]

${ }^{5}$ Antel, J.; Gregory, P. C.; Nordheim, U. J. Med. Chem. 2006, 49, 4008. [CrossRef] [PubMed]

${ }^{6}$ James, P. T.; Rigby, N.; Leach, R.; International Obesity Task Force. Eur. J. Cardiovasc. Prev. Rehabil. 2004, 11, 3. [CrossRef] [PubMed]

7 Flegal, K. M.; Graubard, B. I.; Williamson, D. F.; Gail, M. H. JAMA. 2007, 298, 2028. [CrossRef] [PubMed]

${ }^{8}$ Stein, C. J.; Colditz, G. A. J. Clin. Endocrinol. Metab. 2004, 89, 2522. [CrossRef] [PubMed]

${ }^{9}$ Bray, G. A. J. Clin. Endocrinol. Metab. 2004, 89, 2583. [CrossRef] [PubMed]

${ }^{10}$ Leblanc, E. S.; O'Connor, E.; Whitlock, E. P.; Patnode, C. D.; Kapka, T. Ann. Intern. Med. 2011, 155, 434. [CrossRef] [PubMed]

${ }^{11}$ Korner, J.; Aronne, L. J. J. Clin. Endocrinol. Metab. 2004, 89, 2616. [CrossRef] [PubMed]

${ }^{12}$ Padwal, R.; Kezouh, A.; Levine, M.; Etminan, M. Int. J. Obes. 2007, 31, 1567. [CrossRef] [PubMed]

${ }^{13}$ Weigle, D. S. J. Clin. Endocrinol Metab. 2003, 88, 2462. [CrossRef] [PubMed]

${ }^{14}$ Boguszewski, C. L.; Paz-Filho, G.; Velloso, L. A. Endokrynol Pol. 2010, 61, 194. [PubMed]

${ }^{15}$ Kawauchi, H.; Kawazoe, I.; Tsubokawa M.; Kishida, M.; Baker, B. I. Nature 1983, 305, 321. [PubMed]

${ }^{16}$ Vaughan, J. M.; Fischer, W. H.; Hoeger, C.; Rivier, J.; Vale, W. Endocrinology 1989, 125, 1660. [CrossRef] [PubMed]

${ }^{17}$ Rossi, M.; Choi, S. J.; O'Shea, D.; Miyoshi, T.; Ghatei, M. A.; Bloom, S. R. Endocrinology 1997, 138, 351. [CrossRef] [PubMed]

${ }^{18}$ Clegg, D. J.; Air, E. L.; Benoit, S. C.; Sakai, R. S.; Seeley, R. J.; Woods S. C. Am. J. Physiol.
Regul. Integr. Comp. Physiol. 2003, 284, R494. [PubMed]

${ }^{19}$ Morens, C.; Nørregaard, P.; Receveur, J. M.; van Dijk, G.; Scheurink, A. J. Brain Res. 2005, 1062, 32. [CrossRef] [PubMed]

${ }^{20}$ Bächner, D.; Kreienkamp, H.; Weise, C.; Buck, F.; Richter D. FEBS Lett. 1999, 457, 522. [CrossRef] [PubMed]

${ }^{21}$ Chambers, J.; Ames, R. S.; Bergsma, D.; Muir, A.; Fitzgerald, L. R.; Hervieu, G.; Dytko, G. M.; Foley, J. J.; Martin, J.; Liu, W. S.; Park, J.; Ellis, C.; Ganguly, S.; Konchar, S.; Cluderay, J.; Leslie, R.; Wilson, S.; Sarau, H. M. Nature 1999, 400, 261. [CrossRef] [PubMed]

${ }^{22}$ Saito, Y.; Nothacker, H-P.; Wang, Z.; Lin, S. H. S.; Leslie, F.; Civelli, O. Nature 1999, 400, 265. [CrossRef] [PubMed]

${ }^{23}$ Lembo, P. M. C.; Grazzini, E.; Cao, J.; Hubatsch, D. A.; Pelletier, M.; Hoffert, C.; StOnge, S.; Pou, C.; Labrecque, J.; Groblewski, T.; O’Donnell, D.; Payza K. ; Ahmad S.; Walker, P. Nat. Cell. Biol. 1999, 1, 267. [CrossRef] [PubMed]

${ }^{24}$ Marsh, D. J.; Weingarth, D. T.; Novi, D. E.; Chen, H. Y.; Trumbauer, M. E.; Chen, A. S.; Guan, X-M.; Jiang, M. M.; Feng, Y.; Camacho, R. E.; Shen, Z.; Frazier, E. G.; Yu, H.; Metzger, J. M.; Kuca, S. J.; Shearman, L. P.; GopalTruter, S.; MacNeil, D. J.; Strack, A. M.; Maclntyre, D. E.; Van der Ploeg, L. H. T.; Quian, S. Proc. Natl. Acad. Sci. U. S. A. 2002, 99, 3240. [CrossRef] [PubMed]

${ }^{25}$ Chen, Y.; Hu, C.; Hsu, C-K.; Zhang, Q.; Bi, C.; Asnicar, M.; Hsiung, H. M.; Fox, N.; Slieker, L. J.; Yang, D. D.; Heiman, H. L.; Shi, Y. Endrocrinology 2002, 143, 2469. [CrossRef] [PubMed]

${ }^{26}$ Borowsky, B.; Durkin, M. M.; Ogozalek, K.; Marzabadi, M. R.; DeLeon, J.; Heurich, R.; Lichtblau, H.; Shaposhnik, Z.; Daniewska, I.; Blackburn, T. P.; Branchek, T. A.; Gerald, C.; Vaysse, P. J.; Forray, C. Nat. Med. 2002, 8, 825. [CrossRef] [PubMed]

${ }^{27}$ Karlsson, C.; Zook, M.; Ciccocioppo, R.; Gehlert, D. R.; Thorsell, A.; Heilig, M.; Cippitelli, A. Pharmacol. Biochem. Behav. 2012, 102, 400. [CrossRef] [PubMed]

${ }^{28}$ Lee, C.; Parks, G. S.; Civelli, O. J. Mol. Neurosci. 2011, 43, 132. [CrossRef] [PubMed] 
${ }^{29}$ An, S.; Cutler, G.; Zhao, J. J.; Huang, S. G.; Tian, H.; Li, W.; Liang, L.; Rich, M.; Bakleh, A.; Du, J.; Chen, J. L.; Dai, K. Proc. Natl. Acad. Sci. U. S. A. 2001, 98, 7576. [CrossRef] [PubMed] ${ }^{30}$ Hill, J.; Duckworth, M.; Murdock, P.; Rennie, G.; Sabido, D. C.; Ames, R. S.; Szekeres, P.; Wilson, S.; Bergsma, D. J.; Gloger, I. S.; Levy, D. S.; Chambers, J. K.; Muir, A. I. J. Biol. Chem. 2001, 276, 20125. [CrossRef] [PubMed]

${ }^{31}$ Tan, C. P.; Sano, H.; Iwaasa, H.; Pan, J.; Sailer, A. W.; Hreniuk, D. L.; Feighner, S. D.; Palyha, O. C.; Pong, S-S.; Figueroa, D. J.; Austin, C. P.; Jiang, M. M.; Yu, H.; Ito, J.; Ito, M.; Ito, M.; Guan, X. M.; MacNeil, D. J.; Kanatani, A.; Van der Ploeg, L. H. T.; Howard, A. D. Genomics 2002, 79, 785. [CrossRef] [PubMed]

${ }^{32}$ Audinot, V.; Lahaye, C.; Suply, T.; Beauverger, P.; Rodriguez, M.; Galizzi, J. P.; Fauchere, J. L.; Boutin, J. A. Br. J. Pharmacol. 2001, 133, 371. [CrossRef] [PubMed]

${ }^{33}$ Audinot,V.;Zuana, O. D.; Fabry, N.; Ouvry, C.; Nosjean, O.; Henlin, J. M.; Fauchère, J. L.; Boutin, J. A. Peptides 2009, 30, 1997. [CrossRef] [PubMed]

${ }^{34}$ Bednarek, M. A.; Hreniuk, D. L.; Tan, C.; Palyha, O. C.; MacNeil, D. J.; Van der Ploeg, L. H.; Howard, A. D.; Feighner, S. D. Biochemistry 2002, 41, 6383. [CrossRef] [PubMed]

${ }^{35}$ Takekawa, S.; Asami, A.; Ishihara, Y.; Terauchi, J.; Kato, K.; Shimomura, Y.; Mori, M.; Murakoshi, H.; Kato, K.; Suzuki, N.; Nishimura, O.; Fujino, M. Eur. J. Pharmacol. 2002, 438, 129. [CrossRef] [PubMed]

${ }^{36}$ Clarck, D. E.; Higgs, C.; Wren, S. P.; Dyke, H. J.; Wong, M.; Norman, D.; Lockey, P. M.; Roach, A. G. J. Med. Chem. 2004, 47, 3962. [CrossRef] [PubMed]

${ }^{37}$ Högberg, T.; Frimurer, T. M.; Sasmal, P. K. Bioorg. Med. Chem. Lett. 2012, 22, 6039. [CrossRef] [PubMed]

${ }^{38}$ Borowsky, B.; Durkin, M. M.; Ogozalek, K.; Marzabadi, M. R.; DeLeon, J.; Heurich, R.; Lichtblau, H.; Shaposhnik, Z.; Daniewska, I.; Blackburn, T. P.; Branchek, T. A.; Gerald, C.; Vaysse, P. J.; Forray, C. Nat. Med. 2002, 8, 825. [CrossRef] [PubMed]

${ }^{39}$ Witty, D. R.; Bateson, J.; Hervieu, G. J.; AlBarazanji, K.; Jeffrey, P.; Hamprecht, D.;
Haynes, A.; Jhonson, C. N.; Muir, A. I.; O'Hanlon, P. J.; Stemp, G.; Stevens, A. J.; Thewlis, K.; Winborn, K. Y. Bioorg. Med. Chem. Lett. 2006, 16, 4872. [CrossRef] [PubMed]

${ }^{40}$ Kasai, S.; Kamata, M.; Masada, S.; Kunitomo, J.; Kamaura, M.; Okawa, T.; Takami, K.; Ogino, H.; Nakano, Y.; Ashina, S.; Watanabe, K.; Kaisho, T.; Imai, Y. N.; Ryu, S.; Nakayama, M.; Nagisa, Y.; Takekawa, S.; Kato, K.; Murata, T.; Suzuki, N.; Ishihara, Y. J. Med Chem. 2012, 55, 4336. [CrossRef] [PubMed]

${ }^{41}$ Carpenter, A. J.; Al-Barazanji, K. A.; Barvian, K. K.; Bishop, M. J.; Britt, C. S.; Cooper, J. P.; Goetz, A. S.; Grizzle, M. K.; Hertzog, D. L.; Ignar, D. M.; Morgan, R. O.; Peckham, G. E.; Speake, J. D.; Swain, W. R. Bioorg. Med. Chem. Lett. 2006, 16, 4994. [CrossRef] [PubMed]

${ }^{42}$ Kanuma, K.; Omodera, K.; Nishiguchi, M.; Funakoshi, T.; Chaki, S.; Nagase, Y.; Lida, I.; Yamaguchi, J. I.; Semple, G.; Tran, T. A.; Sekiguchi, Y. Bioorg. Med. Chem. 2006, 14, 3307. [CrossRef] [PubMed]

${ }^{43}$ Tavares, F. X.; Al-Barazanji, K. A.; Bishop, M. J.; Britt, C. S.; Carlton, D. L.; Cooper, J. P.; Feldman, P. L.; Garrido, D. M.; Goetz, A. S.; Grizzle, M. K.; Hertzog, D. L.; Ignar, D. M.; Lang, D. G.; Mclntyre, M. S.; Ott, R. J.; Peat, A. J.; Zhou, H. Q. J. Med. Chem. 2006, 49, 7108. [CrossRef] [PubMed]

${ }^{44}$ Verty, A. N.; Lockie, S. H.; Stefanidis, A.; Oldfield, B. J. Int. J. Obes. (Lond) 2013, 37, 279. [CrossRef] [PubMed]

${ }^{45}$ Carpenter, A. J.; Al-Barazanji, K. A.; Barvian, K. K.; Bishop, M. J.; Britt, C. S.; Cooper, J. P.; Goetz, A. S.; Grizzle, M. K.; Hertzog, D. L.; Ignar, D. M.; Morgan, R. O.; Peckham, G. E.; Speake, J. D.; Swain, W. R. Bioorg. Med. Chem. Lett. 2006, 16, 4994. [CrossRef] [PubMed]

${ }^{46}$ Huang, C. Q.; Baker, T.; Schwarz, D.; Fan, J.; Heise, C. E.; Zhang, M.; Goodfellow, V. S.; Markison, S.; Gogas, K. R.; Chen, T.; Wang, X. C.; Zhu, Y. F. Bioorg. Med. Chem. Lett. 2005, 15, 3701. [CrossRef] [PubMed]

${ }^{47}$ Ulven, T.; Frimurer, T. M.; Receveur, J. M.; Little, P. B.; Rist, O.; Nørregaard, P. K.; Högberg, T. J. Med. Chem. 2005, 48, 5684. [CrossRef] 
${ }^{48}$ Dyck, B.; Markison, S.; Zhao, L.; Tamiya, J.; Grey, J.; Rowbottom, M. W.; Zhang, M.; Vickers, T.; Sorensen, K.; Norton, C.; Wen, J.; Heise, C. E.; Saunders, J.; Conlon, P.; Madan, A.; Schwarz, D.; Goodfellow, V. S. J. Med. Chem. 2006, 49, 3753. [CrossRef] [PubMed]

${ }^{49}$ Dyck, B.; Zhao, L.; Tamiya, J.; Pontillo, J.; Hudson, S.; Ching, B.; Heise, C. E.; Wen, J.; Norton, C.; Madan, A.; Schwarz, D.; Wade, W.; Goodfellow, V. S. Bioorg. Med. Chem. Lett. 2006, 16, 4237. [CrossRef] [PubMed]

${ }^{50}$ Schwarz, D. A.; Allen, M. M.; Petroski, R. E., Pomeroy, J. E.; Heise, C. E.; Mistry, M. S.; Selkirk, J. V.; Nottebaum, L. M.; Grey, J.; Zhang, M.; Goodfellow, V. S., Maki, R. A. Mol. Cell. Endocrinol. 2006, 259, 1. [CrossRef] [PubMed]

${ }^{51}$ Méndez-Andino, J. L.; Colson, A .O.; Meyers, K. M.; Mitchell, M. C.; Hodge, K.; Howard, J. M.; Kim, N.; Ackley, D. C.; Holbert, J. K.; Mittelstadt, S. W.; Dowty, M. E.; Obringer, C. M.; Suchanek, P.; Reizes, O.; Hu, X. E.; Wos, J. A. Bioorg. Med. Chem. 2007, 15, 2092. [CrossRef] [PubMed]

52 Meyers, K. M.; Kim, N.; Méndez-Andino, J. L.; Hu, X. E.; Mumin, R. N.; Klopfenstein, S. R.; Wos, J. A.; Mitchell, M. C.; Paris, J. L.; Ackley, D. C.; Holbert, J. K.; Mittelstadt, S. W.; Reizes, O. Bioorg. Med. Chem. Lett. 2007, 17, 814. [CrossRef] [PubMed]

${ }^{53}$ Bilodeau, M. T.; Balitza, A. E.; Koester, T. J.; Manley, P. J.; Rodman, L. D.; BuserDoepner, C.; Coll, K. E.; Fernandes, C.; Gibbs, J. B.; Heimbrook, D. C.; Huckle, W. R.; Kohl, N.; Lynch, J. J.; Mao, X.; McFall, R. C.; McLoughlin, D.; Miller-Stein, C. M.; Rickert, K. W.; Sepp-Lorenzino, L.; Shipman, J. M.; Subramanian, R.; Thomas, K. A.; Wong, B. K.; Yu, S.; Hartman, G. D. J. Med. Chem. 2004, 47, 6363. [CrossRef] [PubMed]

${ }^{54}$ Meyers, K. M.; Méndez-Andino, J. L.; Colson, A. O.; Hu, E.; Wos, J. A.; Mitchell, M. C.; Hodge, K.; Howard, J. M.; Paris, J. L.; Dowty, M. E.; Obringer, C. M.; Reizes, 0. Bioorg. Med. Chem. Lett. 2007, 17, 657. [CrossRef] [PubMed]

${ }^{55}$ Meyers, K. M.; Méndez-Andino, J. L.; Colson, A. O.; Warshakoon, N. C.; Wos, J. A.; Mitchell, M. C.; Hodge, K.; Howard, J. M.; Ackley, D. C.; Hol bert, J. K.; Mittelstadt, S. W.;
Dowty, M. E.; Obringer, C. M.; Reizes, O.; Hu, X. E. Bioorg. Med. Chem. Lett. 2007, 17, 819. [CrossRef] [PubMed]

${ }^{56}$ Henderson, A. J.; Deering, D.; Grabowski, J. F.; Hadden, M.; Jiang, X.; Khmelnitsky, Y.; Luche, M.; Surman, M. D.; Cheetham, S.; Vickers, S.; Viggers, J.; Guzzo, P. R. Bioorg. Med. Chem. Lett. 2010, 20, 7024. [CrossRef] [PubMed]

${ }^{57}$ Surman, M. D.; Freeman, E. E.; Grabowski, J. F.; Hadden, M.; Henderson, A. J.; Jiang, G.; Jiang, X. M.; Luche, M.; Khmelnitsky, Y.; Vickers, S.; Viggers, J.; Cheetham, S.; Guzzo, P. R. Bioorg. Med. Chem. Lett. 2010, 20, 7015. [CrossRef] [PubMed]

${ }^{58}$ Kym, P. R.; lyengar, R.; Souers, A. J.; Lynch, J. K.; Judd, A. S.; Gao, J.; Freeman, J.; Mulhern, M.; Zhao, G.; Vasudevan, A.; Wodka, D.; Blackburn, C.; Brown, J.; Che, J. L.; Cullis, C.; Lai, S. J.; LaMarche, M. J.; Marsilje, T.; Roses, J.; Sells, T.; Geddes, B.; Govek, E.; Patane, M.; Fry, D.; Dayton, B. D.; Brodjian, S.; Falls, D.; Brune, M.; Bush, E.; Shapiro, R.; Knourek-Segel, V.; Fey, T., McDowell, C.; Reinhart, G. A.; Preusser, L. C.; Marsh, K., Hernandez, L.; Sham, H. L.; Collins, C. A. J. Med. Chem. 2005, 48, 5888. [CrossRef] [PubMed]

${ }^{59}$ Lynch, J. K.; Freeman, J. C.; Judd, A. S.; lyengar, R.; Mulhern, M.; Zhao, G.; Napier, J. J., Wodka, D., Brodjian, S., Dayton, B. D.; Falls, D., Ogiela, C.; Reilly, R. M.; Campbell, T. J.; Polakowski, J. S.; Hernandez, L.; Marsch, K. C.; Shapiro, R., Knourek-Segel, V.; Droz, B.; Bush, E.; Brune, M., Preusser, L. C.; Fryer, R. M.; Reinhart, G. A.; Houseman, K.; Diaz, G.; Mikhail, A.; Limberis, J. T.; Sham, H. L.; Collins, C. A.; Kym, P. R. J. Med. Chem. 2006, 49, 6569. [CrossRef] [PubMed]

${ }^{60}$ Grey, J.; Dyck, B.; Rowbottom, M. W.; Tamiya, J., Vickers, T. D.; Zhang, M., Zhao, L.; Heise, C. E.; Schwarz, D.; Saunders, J.; Goodfellow, V. S. Bioorg. Med. Chem. Lett. 2005, 15, 999. [CrossRef] [PubMed]

${ }^{61}$ Guo, T.; Hunter, R. C.; Gu, H.; Rokosz, L. L.; Stauffer, T. M.; Hobbs, D. W. Bioorg. Med. Chem. Lett. 2005, 15, 3691. [CrossRef] [PubMed]

${ }^{62}$ Rowbottom, M. W.; Vickers, T. D.; Dyck, B.; Grey, J.; Tamiya, J.; Zhang, M.; Kiankarimi, M.; 
Wu, D.; Dwight, W., Wade, W. S.; Schwarz, D.; Heise, C. E.; Madan, A.; Fisher, A.; Petroski, R.; Goodfellow, V. S. Bioorg. Med. Chem. Lett. 2006, 16, 4450. [CrossRef] [PubMed]

${ }^{63}$ Hudson, S.; Kiankarimi, M.; Rowbottom, M. W.; Vickers, T. D.; Wu, D.; Pontillo, J.; Ching, B.; Dwight, W.; Goodfellow, V. S.; Schwarz, D.; Heise, C. E.; Madan, A.; Wen, J.; Ban, W.; Wang, H., Wade, W. S. Bioorg. Med. Chem. Lett. 2006, 16, 4922. [CrossRef] [PubMed]

${ }^{64}$ Rowbottom, M. W.; Vickers, T. D.; Dyck, B.; Tamiya, J.; Zhang, M.; Zhao, L., Grey, J.; Provencal, D.; Schwarz, D., Heise, C. E., Mistry, M., Fisher, A.; Dong, T.; Hu, T.; Saunders, J.; Goodfellow, V. S. Bioorg. Med. Chem. 2005, 15, 3439. [CrossRef] [PubMed]

${ }^{65}$ Palani, A.; Shapiro, S.; McBriar, M. D.; Clader, J.W.; Greenlee, W. J.; Spar, B.; Kowalski, T. J.; Farley, C.; Cook, J.; Heek, M. V.; Weig, B.; O'Neill, K., Grazino, M.; Hawes, B. J. Med. Chem. 2005, 48, 4746. [CrossRef] [PubMed]

${ }^{66}$ McBriar, M. D.; Guzik, H.; Xu, R.; Paruchova, J.; Li, S.; Palani, A.; Clader, J. W.; Greenlee, W. J.; Hawes, B. E.; Kowalski, T. J.; O'Neill, K.; Spar, B.; Weig, B. J. Med. Chem. 2005, 48, 2274. [CrossRef] [PubMed]

${ }^{67}$ Palani, A.; Shapiro, S.; McBriar, M. D.; Clader, J. W.; Greenlee, W. J.; O'Neill, K.; Hawes, B. Bioorg. Med. Chem. Lett. 2005, 15, 5234. [CrossRef] [PubMed]

${ }^{68}$ Sasikumar, T. K.; Qiang, L.; Burnett, D. A.; Greenlee, W. J.; Hawes, B. E.; Kowalski, T. J.; O'Neill, K.; Spar, B. D.; Weig, B. Bioorg. Med. Chem. Lett. 2006, 16, 5427. [CrossRef] [PubMed]

${ }^{69}$ Clark, D. E.; Higgs, C.; Wren, S. P.; Dyke, H. J.; Wong, M.; Norman, D.; Lockey, P. M.; Roach, A. G. J. Med. Chem. 2004, 47, 3962. [CrossRef] [PubMed]

${ }^{70} \mathrm{Ma}$, V.; Bannon, A. W.; Baumgartner, J.; Hale, C.; Hsieh, F.; Hulme, C.; Rorrer, K.; Salon, J.; van Staden, C.; Tempest, P. Bioorg. Med. Chem. Lett. 2006, 16, 5066. [CrossRef] [PubMed]

${ }^{71}$ Cirauqui, N.; Schrey, A. K.; Galiano, S.; Ceras, J.; Pérez-Silanes, S.; Aldana, I.; Monge, A.; Kühne, R. Bioorg. Med. Chem. 2010, 18, 7365. [CrossRef] [PubMed]
${ }^{72}$ Vasudevan, A.; Wodka, D.; Verzal, M. K.; Souers, A. J.; Gao, J.; Brodjian, S.; Fry, D.; Dayton, B.; Marsh, K. C.; Hernandez, L. E.; Ogiela, C. A.; Collins, C. A.; Kym, P. R. Bioorg. Med. Chem. Lett. 2004, 14, 4879. [CrossRef] [PubMed]

${ }^{73}$ Arienzo, R.; Clark, D. E.; Cramp, S.; Daly, S.; Dyke, H. J.; Lockey, P.; Norman, D.; Roach, A. G.; Stuttle, K.; Tomlinson, M.; Wong, M.; Wren, S. P. Bioorg. Med. Chem. Lett. 2004, 14, 4099. [CrossRef] [PubMed]

${ }^{74}$ Warshakoon, N. C.; Sheville, J.; Bhatt, R. T.; Ji, W.; Méndez-Andino, J. L.; Meyers, K. M.; Kim, N.; Wos, J. A.; Mitchell, C.; Paris, J. L.; Pinney, B. B.; Reizes, O.; Hu, X. E. Bioorg. Med. Chem. Lett. 2006, 16, 5207. [CrossRef] [PubMed]

${ }^{75}$ Palczewski, K.; Kumasaka, T.; Hori, T.; Behnke, C. A.; Motoshima, H.; Fox, B. A.; Le Trong, I.; Teller, D. C.; Okada, T.; Stenkamp, R. E.; Yamamoto, M.; Miyano, M. Science 2000, 289, 739. [CrossRef] [PubMed]

${ }^{76}$ Kanuma, K.; Omodera, K.; Nishiguchi, M.; Funakoshi, T.; Chaki, S.; Semple, G.; Tran, T. A.; Kramer, B.; Hsu, D.; Casper, M.; Thomsen, B.; Sekiguchi, Y. Bioorg. Med. Chem. Lett. 2005, 15, 3853. [CrossRef] [PubMed]

${ }^{77}$ Sasmal, S.; Balasubrahmanyam, D.; Kanna Reddy, H. R.; Balaji, G.; Srinivas, G.; Cheera, S.; Abbineni, C.; Sasmal, P. K.; Khanna, I.; Sebastian, V. J.; Jadhav, V. P.; Singh, M. P.; Talwar, R.; Suresh, J.; Shashikumar, D.; Harinder Reddy, K.; Sihorkar, V.; Frimurer, T. M.; Rist, $\varnothing$.; Elster, L.; Högberg, T. Bioorg. Med. Chem. Lett. 2012, 22, 3163. [CrossRef] [PubMed]

${ }^{78}$ Mihalic, J.T.; Chen, X.; Fan, P.; Chen, X.; Fu, Y.; Liang, L.; Reed, M.; Tang, L.; Chen, J. L.; Jaen, J.; Li, L.; Dai, K. Bioorg. Med. Chem. Lett. 2011, 21, 7001. [CrossRef] [PubMed]

${ }^{79}$ Lim, C. J.; Kim, N.; Lee, E. K.; Lee, B. H.; Oh, K. S.; Yoo, S. E.; Yi, K. Y. Bioorg. Med. Chem. Lett. 2011, 21, 2309. [CrossRef] [PubMed] ${ }^{80}$ Rivera, G.; Bocanegra-García, V.; Galiano, S.; Cirauqui, N.; Ceras, J.; Pérez, S.; Aldana, I.; Monge, A. Curr. Med. Chem. 2008, 15, 1025. [CrossRef] [PubMed] 